\title{
Stromelysin-1 Gene Promoter 5A/6A Polymorphism and Plasma C-Reactive Protein in Patients with Coronary Artery Disease and Myocardial Infarction
}

\author{
Jing-Ren Jeng \\ Division of Cardiology, Departments of Internal Medicine, Buddhist Tzu Chi General Hospital, Tzu Chi University, \\ Haulien, Taiwan \\ Email:.jrj4511@gmail.com,jrjeng@tzuchi.com.tw
}

Received 14 July 2016; accepted 8 August 2016; published 11 August 2016

Copyright (C) 2016 by author and Scientific Research Publishing Inc.

This work is licensed under the Creative Commons Attribution International License (CC BY).

http://creativecommons.org/licenses/by/4.0/

(c) (i) Open Access

\begin{abstract}
Objective: To study the associations of stromelysin-1 (MMP3) gene 5A/6A polymorphism with plasma high-sensitivity C-reactive protein (hs-CRP) level in coronary artery disease (CAD) and myocardial infarction (MI). Methods: The MMP3 5A/6A genotypes and plasma hs-CRP levels were determined in 405 non-CAD subjects and 395 angiography-documented CAD patients, 157 with MI and 238 with non-MI. Results: The percentage of the $5 A / 5 A$ genotype was significantly $(p<0.001)$ greater in CAD than non-CAD subjects and in MI than non-MI patients. Plasma hs-CRP level of the $5 A / 5 A$ genotype was significantly $(p<0.05)$ higher than that of the $6 A / 6 A$ genotype in CAD and MI but not in non-MI patients. On logistic regression analysis, the odds ratio of the $5 \mathrm{~A} / 5 \mathrm{~A}$ genotype for CAD was $2.11(95 \% \mathrm{CI}, 1.15-3.88, \mathrm{p}<0.05)$ and for MI was $3.05(95 \% \mathrm{CI}, 1.54-6.04, \mathrm{p}<0.005)$. Conclusions: This study showed a correlation of the $5 \mathrm{~A} / 5 \mathrm{~A}$ genotype of MMP3 promoter with higher plasma hs-CRP level in CAD patients with MI.
\end{abstract}

\section{Keywords}

Stromelysin-1, Gene Polymorphisms, C-Reactive Protein, Coronary Artery Disease, Myocardial Infarction

\section{Introduction}

Rupture of atherosclerotic plaque plays a critical role in acute coronary syndrome (ACS) and myocardial infarction 
(MI) in patients with coronary artery disease (CAD) [1]. Stromelysin-1 (MMP3) may be involved in plaque rupture because it can cleave the extracellular matrix (ECM) proteins [2]. Ye et al. [3] identified a common polymorphism in the promoter of MMP3 gene, located 1171 bp upstream from the transcription, with one allele having a run of six adenosines (6A) and the other having five adenosines (5A). In vitro and ex vivo studies showed that the $5 \mathrm{~A}$ allele and the $5 \mathrm{~A} / 5 \mathrm{~A}$ genotype had greater MMP3 promoter activity, mRNA and protein than the $6 \mathrm{~A}$ allele and the 6A/6A genotype [4] [5]. In the meta-analysis studies [6]-[8], the 5A allele was associated with acute MI [6] [7], and the effect of the 5A/6A genotypes on CAD risk was ethnicity-specific and more prominent for MI patients or East Asians [8]. Xu et al. [9] further reported that the 5A/5A genotype was associated with a risk for ACS in the Chinese.

Plasma high sensitivity C-reactive protein (hs-CRP) has been shown to be a predictor of future MI among clinically healthy peoples [10]. Elevated hs-CRP level was associated with an increased risk of further coronary events and rapid disease progression in CAD patients [11]. It was suggested that plasma hs-CRP level might be a marker of CAD activity and plaque vulnerability [12]. In our previous study [13], plasma hs-CRP level was correlated to the extent and severity of $\mathrm{CAD}$, and associated with the gene promoter $17 \mathrm{~A} / 21 \mathrm{~A}$ polymorphisms of 5-lipoxygenase activating protein, a regulator in the genesis of leukotrienes.

In this study, the MMP3 5A/6A genotypes and plasma hs-CRP level were determined in a hospital-based population to investigate the associations of the $5 \mathrm{~A} / 6 \mathrm{~A}$ genotypes with plasma hs-CRP levels in CAD and MI patients. The distribution of the 5A/6A genotypes was compared between CAD and non-CAD subjects, and between MI and non-MI patients. The odds ratios of the 5A/6A genotypes for CAD and MI were analyzed.

\section{Methods}

This study included 395 Chinese patients with CAD diagnosed by coronary angiography of at least $50 \%$ diameter stenosis in vessels and 405 healthy subjects without clinical evidences of either CAD or MI. They were recruited from the cardiology ward and health examination center of the Tri-Service General Hospital, Taipei, Taiwan. Based on the history taking, physical examination, laboratory data, electrocardiography and echocardiogram, 157 CAD patients were found to have previous MI and 238 cases showed no evidence of MI. They volunteered to join this study following a protocol approved by the National Defense Medical Center Human Subjects Committee.

Blood was drawn after an overnight fast, and plasma separated and stored at $-70^{\circ} \mathrm{C}$. Glucose, total cholesterol, triglyceride, and hs-CRP were determined with commercially available kits as described previously [13]-[15]. Genomic DNA was extracted from buffy coat using an IsoQuick Nucleic Acid Extraction Kit (MicroProbe, Bothell, WA). The 5A/6A polymorphism of the MMP3 gene was determined by a polymerase chain reaction and restriction fragment length polymorphism analysis with Tth111I enzyme digestion [16]. The method was validated by genotype confirmation through direct sequencing.

Data in all groups are reported as means \pm SD. The difference between two groups was examined by Student's t test. One-way analysis of variance was used to evaluate the difference among three genotypic groups. The difference of genotype distribution and allele frequency between two groups was examined by Chi-square test. Multivariate logistic regression was employed to calculate the odds ratio of the 5A/6A genotypes for CAD and MI, controlling the potential confounding factors. The statistic significance of difference was assumed to be present at $\mathrm{p}$ value $<0.05$.

\section{Results}

The characteristics of 405 non-CAD subjects and 395 CAD patients with MI or non-MI are shown in Table 1. CAD patients had significantly higher age, percentage of men, body mass index, prevalence of hypertension, diabetes, hyperlipidemia and smoking, and fasting plasma levels of glucose, total cholesterol, and triglyceride than non-CAD subjects. The percentage of smoking was significantly greater in MI than non-MI patients. CAD patients, with MI or non-MI, had significantly higher plasma hs-CRP levels than non-CAD subjects.

The distributions of the 5A/6A genotypes and allele frequencies of MMP3 promoter in non-CAD subjects and CAD patients, with MI and non-MI, are reported in Table 2. The 5A/6A genotype and allele frequencies in the control non-CAD group agree with those predicted by Hardy-Weinberg equilibrium. The 5A/5A genotype percentage of MMP3 was significantly greater in CAD patients than non-CAD subjects $(13.2 \%$ vs. $8.4 \%$, p < $0.001)$, but the $5 \mathrm{~A}$ allele frequency was not $(0.239 \mathrm{vs.} 0.274)$. MI patients had significantly higher percentage of 
Table 1. Characteristics of 405 non-CAD subjects and 395 CAD patients with MI and non-MI.

\begin{tabular}{|c|c|c|c|c|}
\hline & Non-CAD $(n=405)$ & $\mathrm{CAD}(\mathrm{n}=395)$ & Non-MI CAD $(n=238)$ & MI CAD $(n=157)$ \\
\hline Age, years & $55.3 \pm 10.4$ & $65.2 \pm 12.1^{* * *}$ & $66.0 \pm 11.0$ & $64.0 \pm 13.6$ \\
\hline Gender, women/men & $190 / 213$ & $131 / 264^{* * * *}$ & $86 / 152$ & 45114 \\
\hline Body mass index, $\mathrm{kg} / \mathrm{m}^{2}$ & $24.2 \pm 3.7$ & $25.2 \pm 3.7^{* * *}$ & $25.4 \pm 3.6$ & $25.0 \pm 4.0$ \\
\hline Hypertension, \% & 20 & $65^{* * *}$ & 63 & 67 \\
\hline Diabetes, \% & 11 & $43^{* * *}$ & 39 & 48 \\
\hline Hypercholesterolemia, \% & 14 & $24^{* *}$ & 23 & 26 \\
\hline Hypertriglyceridemia, \% & 19 & $37^{* * *}$ & 36 & 37 \\
\hline Smoking, \% & 31 & $49^{* * *}$ & 42 & $59 * *$ \\
\hline Fasting glucose, mg/dl & $108.2 \pm 37.1$ & $137.4 \pm 60.9^{* * *}$ & $134.5 \pm 61.4$ & $141.8 \pm 60.1$ \\
\hline Total cholesterol, mg/dl & $179.4 \pm 38.7$ & $198.7 \pm 47.2^{* * *}$ & $199.2 \pm 45.1$ & $198.1 \pm 50.0$ \\
\hline Triglyceride, mg/dl & $129.7 \pm 110.6$ & $158.0 \pm 86.2^{* * * *}$ & $157.9 \pm 90.3$ & $158.1 \pm 79.9$ \\
\hline C-reactive protein, mg/l & $0.12 \pm 0.13$ & $1.93 \pm 3.15^{* * *}$ & $1.17 \pm 2.64$ & $3.15 \pm 5.99^{* * *}$ \\
\hline
\end{tabular}

$\mathrm{CAD}=$ coronary artery disease; $\mathrm{MI}=$ myocardial infarction. Data are expressed as means $\pm \mathrm{SD} .{ }^{*} \mathrm{p}<0.05,{ }^{* *} \mathrm{p}<0.01,{ }^{* * * *} \mathrm{p}<0.001$ by Student's $\mathrm{t}$ test, either between non-CAD subjects and CAD patients or between CAD with MI and non-MI.

Table 2. The 5A/6A genotype percentages and allele frequencies of MMP3 promoter in non-CAD subjects and CAD patients, with MI and non-MI.

\begin{tabular}{|c|c|c|c|c|c|c|c|c|c|}
\hline & $5 \mathrm{~A} / 5 \mathrm{~A}$ & $5 \mathrm{~A} / 6 \mathrm{~A}$ & $6 \mathrm{~A} / 6 \mathrm{~A}$ & $\chi^{2}$ & $\mathrm{P}$ & $5 \mathrm{~A}$ & $6 \mathrm{~A}$ & $\chi^{2}$ & $\mathrm{p}$ \\
\hline $\begin{array}{l}\text { Non-CAD } \\
(\mathrm{n}=405)\end{array}$ & $\begin{array}{c}34 \\
(8.4 \%)\end{array}$ & $\begin{array}{c}154 \\
(38 \%)\end{array}$ & $\begin{array}{c}217 \\
(53.6 \%)\end{array}$ & & & $\begin{array}{c}222 \\
(27.4 \%)\end{array}$ & $\begin{array}{c}588 \\
(72.6 \%)\end{array}$ & & \\
\hline $\begin{array}{l}\text { CAD patients } \\
(\mathrm{n}=395)\end{array}$ & $\begin{array}{c}52 \\
(13.2 \%)\end{array}$ & $\begin{array}{c}85 \\
(21.5 \%)\end{array}$ & $\begin{array}{c}258 \\
(65.4 \%)\end{array}$ & 27.1 & $<0.001$ & $\begin{array}{c}189 \\
(23.9 \%)\end{array}$ & $\begin{array}{c}601 \\
(76.1 \%)\end{array}$ & 2.5 & NS \\
\hline $\begin{array}{l}\text { MI CAD } \\
(\mathrm{n}=238)\end{array}$ & $\begin{array}{c}21 \\
(8.8 \%)\end{array}$ & $\begin{array}{c}46 \\
(19.3 \%)\end{array}$ & $\begin{array}{c}171 \\
(71.8 \%)\end{array}$ & & & $\begin{array}{c}88 \\
(18.5 \%)\end{array}$ & $\begin{array}{c}388 \\
(81.5 \%)\end{array}$ & & \\
\hline $\begin{array}{l}\text { Non-MI CAD } \\
\quad(\mathrm{n}=157)\end{array}$ & $\begin{array}{c}31 \\
(19.7 \%)\end{array}$ & $\begin{array}{c}39 \\
(24.8 \%)\end{array}$ & $\begin{array}{c}87 \\
(55.4 \%)\end{array}$ & 13.8 & $<0.001$ & $\begin{array}{c}101 \\
(32.2 \%)\end{array}$ & $\begin{array}{c}213 \\
(67.8 \%)\end{array}$ & 19.4 & $<0.001$ \\
\hline
\end{tabular}

$\mathrm{CAD}=$ coronary artery disease; $\mathrm{MI}=$ myocardial infarction; MMP3 = stromelysin-1. $\chi^{2}$ and p values were obtained from Chi-square test between non-CAD and CAD patients, and between MI and non-MI CAD.

the $5 \mathrm{~A} / 5 \mathrm{~A}$ genotype $(19.7 \%$ vs. $8.8 \%, \mathrm{p}<0.001)$ than non-MI, and the $5 \mathrm{~A}$ allele frequency was significantly greater in MI than non-MI (0.322 vs. 0.185, $\mathrm{p}<0.001)$. The odds ratio of the $5 \mathrm{~A} / 5 \mathrm{~A}$ genotype was significant higher for CAD $(2.11,95 \% \mathrm{CI}=1.15-3.88, \mathrm{p}<0.05)$ and for MI $(3.05,95 \% \mathrm{CI}=1.54-6.04, \mathrm{p}<0.005)$ but not for non-MI $(1.48, \mathrm{CI}=0.72-3.04, \mathrm{p}>0.05)$ on multivariate logistic regression analysis controlling potential confounding factors.

Table 3 presents the plasma hs-CRP data of 405 non-CAD subjects and 395 CAD patients with non-MI or MI grouped by the MMP3 5A/6A genotypes. Plasma hs-CRP level of the 5A/5A genotype was significantly higher than that of the $6 \mathrm{~A} / 6 \mathrm{~A}$ genotype in CAD $(3.33 \pm 7.52 \mathrm{vs} .1 .53 \pm 3.04 \mathrm{mg} / \mathrm{l}, \mathrm{p}<0.05)$ and in $\mathrm{MI}(4.73 \pm 9.40 \mathrm{vs}$. $2.20 \pm 3.17 \mathrm{mg} / \mathrm{l}, \mathrm{p}<0.05$ ) patients. However, there was no significant difference on plasma hs-CRP levels among three genotypic groups in non-CAD subjects and in non-MI patients.

\section{Discussion}

This study, consistent with the previous reports [6]-[9] [17] [18], found that the 5A/5A genotype had an increased risk for CAD, especially for MI, supporting the concept that CAD patients having this genotype with greater MMP3 promoter activity could predispose to higher incidence of MI. More importantly, the elevated 
Table 3. Plasma C-reactive protein levels in 405 healthy non-CAD subjects and 395 CAD patients grouped by MMP3 5A/6A genotypes.

\begin{tabular}{ccccc}
\hline & $5 \mathrm{~A} / 5 \mathrm{~A}$ & $5 \mathrm{~A} / 6 \mathrm{~A}$ & $6 \mathrm{~A} / 6 \mathrm{~A}$ & $\mathrm{p}$ \\
\hline Non-CAD & $0.15 \pm 0.22$ & $0.14 \pm 0.28$ & $0.14 \pm 0.17$ & $\mathrm{NS}$ \\
CAD patients & $3.33 \pm 7.52$ & $2.38 \pm 4.93$ & $1.50 \pm 3.02$ & $<0.05$ \\
Non-MI CAD & $1.27 \pm 2.02$ & $1.03 \pm 1.54$ & $1.20 \pm 2.9$ & $\mathrm{NS}$ \\
MI CAD & $4.73 \pm 9.41$ & $3.96 \pm 6.79$ & $2.04 \pm 3.09$ & $<0.05$ \\
\hline
\end{tabular}

$\mathrm{CAD}=$ coronary artery disease; $\mathrm{MI}=$ myocardial infarction; $\mathrm{MMP} 3=$ stromelysin- 1. Data are expressed as mean $\pm \mathrm{SD}(\mathrm{mg} / \mathrm{l}) . \mathrm{p}$ values obtained from one-way analysis of variance.

plasma hs-CRP level in the 5A/5A genotype was significant in CAD patients with MI but not in non-MI, suggesting CAD patients with this genotype might have greater vascular inflammation susceptible to the occurrence of MI. The increased proteolytic activity of the 5A/5A genotype with higher MMP3 level could favor the ECM proteins degradation with rupture of plaque cap, and thus lead to elevated plasma hs-CRP level in CAD patients. The association of the 5A/5A genotype with elevated plasma hs-CRP level in MI patients might suggest a possible linkage between higher MMP3 promoter activity and greater vascular inflammation in the process of atherosclerotic plaque rupture.

\section{Conclusion}

In conclusion, this study showed that the 5A/5A genotype of MMP3 promoter was associated with higher plasma hs-CRP level and greater risk for MI in CAD patients. The results might suggest the 5A/5A genotype of MMP3 with greater vascular inflammation could be a genetic risk factor for MI in the Chinese population at Taiwan.

\section{Acknowledgements}

This study was supported by a grant from the National Science Council, Taipei, Taiwan.

\section{Conflict of Interest}

There is no conflict of interest.

\section{References}

[1] Falk, E., Sha, P.K. and Fuster, V. (1995) Coronary Plaque Disruption. Circulation, 92, 657-671. http://dx.doi.org/10.1161/01.CIR.92.3.657

[2] Galis, Z.S., Sukhova, G.K., Lark, M.W. and Libby, P. (1994) Increased Expression of Matrix Matalloproteinases and Matrix Degrading Activity in Vulnerable Regions of Human Atherosclerotic Plaques. Journal of Clinical Investigation, 94, 2493-2503. http://dx.doi.org/10.1172/JCI117619

[3] Ye, S., Watts, G.F., Mandalia, S., et al. (1995) Preliminary Report: Genetic Variation in the Human Stromelysin Promoter Is Associated with Progression of Coronary Atherosclerosis. British Heart Journal, 73, 209-215. http://dx.doi.org/10.1136/hrt.73.3.209

[4] Ye, S., Eriksson, P., Hansten, A., et al. (1996) Progression of Coronary Atherosclerosis Is Associated with a Common Genetic Variant of the Human Stromelysin-1 Promoter Which Results in Reduced Gene Expression. Journal of Biological Chemistry, 271, 13055-13060. http://dx.doi.org/10.1074/jbc.271.22.13055

[5] Medley, T.L., Kingwell, B.A., Gatzka, C.D., et al. (2003) Matrix Metalloproteinase-3 Genotype Contributes to AgeRelated Aortic Stiffening through Modulation of Gene and Protein Expression. Circulation Research, 92, 1254-1261. http://dx.doi.org/10.1161/01.RES.0000076891.24317.CA

[6] Abilleria, S., Bevan, S. and Markus, H.S. (2006) The Role of Genetic Variants of Matrix Metalloproteintases in Coronary and Carotid Atherosclerosis. Journal of Medical Genetics, 43, 897-901. http://dx.doi.org/10.1136/jmg.2006.040808

[7] Wang, J., Xu, D., Wu, X., et al. (2011) Polymorphisms of Matrix Metalloproteinases in Myocardial Infarction: A MetaAnalysis. Heart, 97, 1542-1546. http://dx.doi.org/10.1136/heartjnl-2011-300342 
[8] Niu, W. and Qi, Y. (2012) Matrix Metalloproteinase Family Gene Polymorphisms and Risk for Coronary Artery Disease: Systemic Review and Meta-Analysis. Heart, 98, 1483-1491. http://dx.doi.org/10.1136/heartjnl-2012-302085

[9] Xu, X., Wang, L., Xu, C., et al. (2013) Variations in Matrix Metalloproteinase-1, -3 and -9 Genes and the Risk of Acute Coronary Syndrome and Coronary Artery Disease in the Chinese Han Population. Coronary Artery Disease, 24, 259-265. http://dx.doi.org/10.1097/MCA.0b013e32835ea3af

[10] Ridker, P.M., Buring, J.E., Shih, J., et al (1998) Prospective Study of C-Reactive Protein and the Risk of Future Cardiovascular Events among Apparently Healthy Women. Circulation, 98, 731-733. http://dx.doi.org/10.1161/01.CIR.98.8.731

[11] Zouridakis, E., Avanzas, P., Arroyo-Espliguero, R., et al. (2004) Markers of Inflammation and Rapid Coronary Artery Disease Progression in Patients with Stable Angina Pectoris. Circulation, 110, 1747-1753. http://dx.doi.org/10.1161/01.CIR.0000142664.18739.92

[12] Arroyo-Espliguero, R., Avanza, P., Cosin-Sales, J., et al. (2004) C-Reactive Protein Elevation and Disease Activity in Patients with Coronary Artery Disease. European Heart Journal, 25, 401-408. http://dx.doi.org/10.1016/j.ehj.2003.12.017

[13] Jeng, J.R. (2008) Plasma C-Reactive Protein and 5-Lipoxygenase Activating Protein Gene Promoter Poly-A Polymorphism in Patients with Coronary Artery Disease. Cardiology, 109, 25-32. http://dx.doi.org/10.1159/000105323

[14] Jeng, J.R. (2003) Association of PAI-1 Gene Promoter 4G/5G Polymorphism with Plasma PAI-1 Activity in Chinese Patients with and without Hypertension. American Journal of Hypertension, 16, 290-296. http://dx.doi.org/10.1016/S0895-7061(03)00004-9

[15] Jeng, J.R., Wang, J.H., Liu, W.S., et al. (2005) Association of Interleukin-6 Gene G-174C Polymorphism and Plasma Plasminogen Activator Inhibitor-1 Level in Chinese Patients with and without Hypertension. American Journal of Hypertension, 18, 517-522. http://dx.doi.org/10.1016/j.amjhyper.2004.10.028

[16] Gnasso, A., Motti, C., Irace, C., et al. (2000) Genetic Variation in Human Stromelysin-1 Gene Promoter and Common Carotid Geometry in Healthy Male Subjects. Arteriosclerosis, Thrombosis, and Vascular Biology, 20, 1600-1605. http://dx.doi.org/10.1161/01.ATV.20.6.1600

[17] Nojiri, T., Morita, H., Imai, Y., et al. (2003) Genetic Variations of Matrix Metalloproteinase-1 and -3 Promoter Regions and Their Associations with Susceptibility to Myocardial Infarction in Japanese. International Journal of Cardiology, 92, 181-186. http://dx.doi.org/10.1016/S0167-5273(03)00100-1

[18] Ghaderian, S.M., Akbarzadeh Najar, R. and Tabatabaei Panah, A.S. (2012) Genetic Polymorphisms and Plasma Levels of Matrix Metalloproteinases and Their Relationships with Developing Acute Myocardial Infarction. Coronary Artery Disease, 21, 330-335. http://dx.doi.org/10.1097/MCA.0b013e32833ce065

\section{Submit or recommend next manuscript to SCIRP and we will provide best service for you:}

Accepting pre-submission inquiries through Email, Facebook, LinkedIn, Twitter, etc.

A wide selection of journals (inclusive of 9 subjects, more than 200 journals)

Providing 24-hour high-quality service

User-friendly online submission system

Fair and swift peer-review system

Efficient typesetting and proofreading procedure

Display of the result of downloads and visits, as well as the number of cited articles

Maximum dissemination of your research work

Submit your manuscript at: http://papersubmission.scirp.org/ 